\title{
The Long-Run and Short-Run Relationship between the Exchange Rates and Stock Market Prices
}

\author{
Clement Mwaanga, Nsama Njebele \\ Department of Business Studies, Mulungushi University, Kabwe, Zambia \\ Email: cmwaanga@mu.ac.zm, mwaanga.clement@yahoo.co.uk,nsama.musawa@yahoo.com,nnjebele@mu.ac.zm
}

How to cite this paper: Mwaanga, C., \& Njebele, N. (2017). The Long-Run and Short-Run Relationship between the Exchange Rates and Stock Market Prices. Journal of Financial Risk Management, 6, 315-324.

https://doi.org/10.4236/jfrm.2017.64023

Received: September 19, 2017

Accepted: October 30, 2017

Published: November 2, 2017

Copyright ( 92017 by authors and Scientific Research Publishing Inc. This work is licensed under the Creative Commons Attribution International License (CC BY 4.0).

http://creativecommons.org/licenses/by/4.0/

\begin{abstract}
The aim of this study was to investigate the relationship between the exchange rate and the stock market price in Zambia using the time series monthly data from 2004 to 2016. To measure the stock market prices, we used LuSE overall index (LuSE Index) and the exchange rate was measured using the Zambia's Real Effective Exchange Rate (REER). In order to establish the relationship between the exchange rate and the stock market price, we employed the Vector Autoregression (VAR) based cointegration test methodology and Auto Regression distribution lag (ARDL) bound tests. The Johansson cointegration test results revealed the existence of the cointegration long run. However the Auto Regression distribution lag bound tests show that its impact is statistically insignificant. The Vector Error Correction Model (VECM) revealed that there is no short-run relationship between the exchange rate and stock market prices. The findings of this study have implications for academicians, policy makers and investors.
\end{abstract}

\section{Keywords}

Exchange Rates, Stock Market Prices, Investors, Economic Growth

\section{Introduction}

Stock markets are considered to be the conduit for boosting domestic savings and at the same time enhances the quality and quantity of investment in an economy (Yartey \& Komla, 2007). In addition, stock market encourages individual savings and enhances firm financing, which results in economic growth (Odhiambo, 2012). Furthermore, equity market and the currency market play a pivotal role in economic development (Singh, 2015). However, the Lusaka stock 
exchange market (LuSE) has not performed well in the last few years with share price index down by $26.83 \%$ in local currency compared to other Sub-Sahara African countries (http://www.africa-mrket.com/).

Studies on the relationship between the stock markets and economic growth have gained significant attention amongst scholars, investors and policy makers (Iscan, 2014). The interest in this relationship has made scholars to study the macroeconomic factors that influence the performance of stock markets. One of the factors widely studied is the exchange rate. According to the UNECA (2015) report, policy makers and investors pay attention to the exchange rate fluctuations because their impact on the efforts to reduce inflation. In the recent past, the Zambian currency has been under pressure resulting in depreciation from K3.75 to the United States Dollar in 2008 to K11 in 2015 (UNECA, 2015) as shown in Figure 1 below. From the Figure 1 below it can be seen that the local currency witnessed a sharp appreciation and the Kwacha traded at K5.05 to the dollars in 2009 as compared to 2008. This depreciation of the currency continued and by 2014, the rate was K6.15 to the dollar. At the end of 2015 the currency was quoted at K10.99 to the Dollar.

Although the exchange rate is one of the significant factors affecting the performance of stock markets, there is a shortage of studies done to provide empirical evidence in developing countries Zambia in particular. One recent study done by Sichoongwe (2016) investigated the impact of exchange rate and interest rate volatility on the stock market prices. This study employed the GARCH (1.1) approach. According to our knowledge, there in no study carried out in Zambia to determine the impact of the exchange rate on the Lusaka stock market (LuSE) performance using Auto Regression Distribution Lag and Cointegration Analysis and Vector Error Correction Model. Most of the studies done in this regard focus on developed and emerging economies (Wongbangpo \& Sharma, 2002). However, Singh (1999) suggested that stock markets in developing countries,

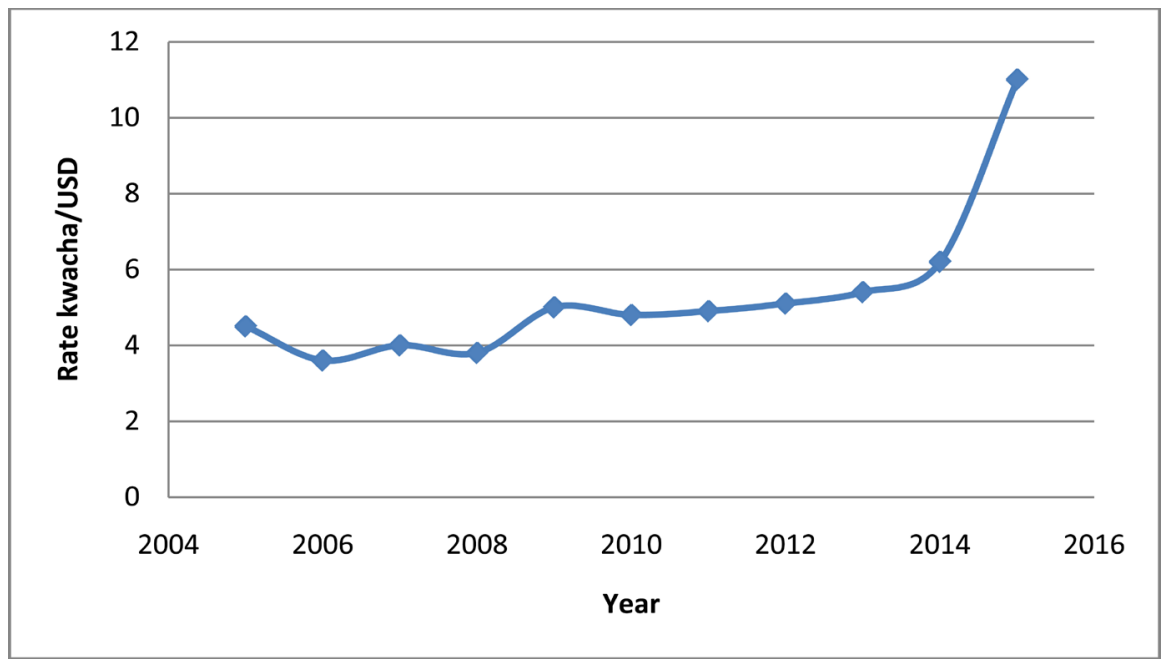

Source: Bank of Zambia (2016)

Figure 1. Exchange rate development (2005-2015). 
particularly Africa may not perform well because of the huge costs involved and improper financial structure.

In this study by using auto regression distribution lag and cointegration analysis and the vector error correction model on the variables (exchange rate and stock index) from 2004 to 2016, the impact of exchange rate on the performance of the stock market will be established. Therefore, this study was an attempt to establish the short and long term relationship between the exchange rate and the stock prices.

This study provides a contribution to the empirical literature by establishing the short and long term relationship between the exchange rate and stock price in the developing country context. At a practical level, the study provides knowledge required by policy makers to formulate policies that will spur economic growth in Zambia and investors to evaluate the implications of exchange rate fluctuations on the stock market performance because the stock market is the most sensitive market in an economy. Both researcher and investors or practitioners are interested in understanding the variables that affect economic growth and how these variables can be managed.

The rest of the paper is structured as follows: the review of the literature is done in Section 2, Data and Methodology presented in Section 3, the research findings and discussions in Section 4 and the conclusion in Section 5.

\section{Literature Review}

The literature has shown that studies on the relationship between the stock market prices and the exchange rate have gained popularity among scholars over the past 25 years (Singh, 2015). Despite the increase in popularity, most of these studies have revealed inconclusive results.

The earlier study by Mishra (2004) examined the relationship between the exchange rate and the stock market prices using data from 1992 to 2003 . The findings suggested that there is no Granger causality between the exchange rate and the stock market prices.

Zia \& Rahman (2011) investigated the relationship between the exchange rate and the stock market prices. In their study, the employed cointegration technique and the Eagle-Granger causality tests. The results of the study showed that there was no long-run relationship between the exchange rate and the stock market prices.

Komain (2012) adopted GARCH model and Granger causality test in a study conducted in Thailand and investigated the relationship between the exchange rate and the stock market prices. The data used in the study covered the period from 1997 to 2010 and the findings revealed that there was no long-run relationship between the two variables.

Mlambo et al. (2013) conducted a study in South Africa using the data from the period 2000 to 2010 to establish the relationship between the stock market prices and the exchange rate. The findings revealed a weak relationship between 
the two variables.

A recent study conducted in Pakistan by Khan \& Ali (2015) on the relationship between exchange rate and the stock market prices using the Granger causality test showed a bidirectional relationship between exchange rate and stock market prices.

Singh (2015) investigated the relationship between the stock market prices and the exchange rate in India. The study employed Johansen's cointegration and Granger causality tests using the data from 2007 to 2014. The findings of this study indicated cointegration between the exchange rate and the stock market prices, which shows that there is a long-run relationship between the two variables. In contrast, Suriani (2015) investigated the relationship between the exchange rate and the stock market prices in Pakistan. The study used the Augmented Dickey Fuller (ADF) tests and the results revealed no relationship between exchange rate and the stock market prices.

A recent study carried out in Zambia by Sichoongwe (2016) investigated the impact of exchange rate volatility on the stock market performance employing the GARCH econometric model. The findings pointed to a negatively related relationship between the exchange rate and the stock market prices. However, employing a number of statistical techniques such as ADF tests, correlation, OLS regression, cointegration tests, Granger causality tests, VAR model and GARCH, a study conducted by Branidharan (2016) revealed a long-run relationship between the exchange rate and the stock market prices. Their study employed data from the period April 2002 to March 2010.

From the literature review above, it can be seen that both early and more recent studies have revealed mixed results about the relationship between the exchange rate and the stock market prices. A number of factors have influenced the results such as the methodologies used in these studies, the time period of the data and the context specific factors (countries financial regulations and investor preferences and incentives). Most of the recent studies that have used VAR and ADF tests have used data of a shorter period of time. This employed a number of statistical tests and used the data from 2004 to 2014 to establish the short-run and the long-run relationship between the exchange rate and stock market index in the developing economy' context.

\section{Data and Methodology}

\subsection{Data}

This study employed monthly data covering the period from 2004 to 2016 . This period includes the data from the period of the global financial crisis, which did not have a significant impact on Zambia. To measure the stock market prices, we used LuSE overall index (LuSE Index). We also measured the exchange rate using the Real Effective Exchange Rate (REER). The data for both the stock market prices and the exchange rate was obtained from the Bank of Zambia. 


\subsection{Methodology}

Like in similar research, Nordin and Ismail (2014), this research utilized the Vector Autoregression (VAR) based cointegration test methodology by Johansen (1996) and Auto Regression distribution lag (ARDL) bound tests to analyse the Impact of Exchange rate on the stock market in Zambia using the E Views software.

The VAR involves the use of regression equations in which all the elements of variables are regarded to be endogenous and each element is explained by its lagged or past values which are all included in the model. In this model exogenous variables are not included. The ARDL model is model used to examine the co-movement of variables under investigation.

Before the estimation was done some diagnostic test were done among them was the normality test for the dependent variable, and the Unit root test. To perform the Vector Error Correction, three steps were followed 1) Lag length selection 2) cointegration test and 3) Auto Regression distribution lag bound tests.

\section{Results}

This section shows how graphical analysis and econometric models were used to analyze the dataon the LuSe price index and exchange rate. The graphic analysis compares the dependent variable LuSe price index and independent variables exchange rate.

\subsection{Graphical Analysis}

A graphical analysis of the data on LuSe Price Index and Exchange Rate (REER) is shown in Figure 2 below. While the LuSE index had an upward trend the

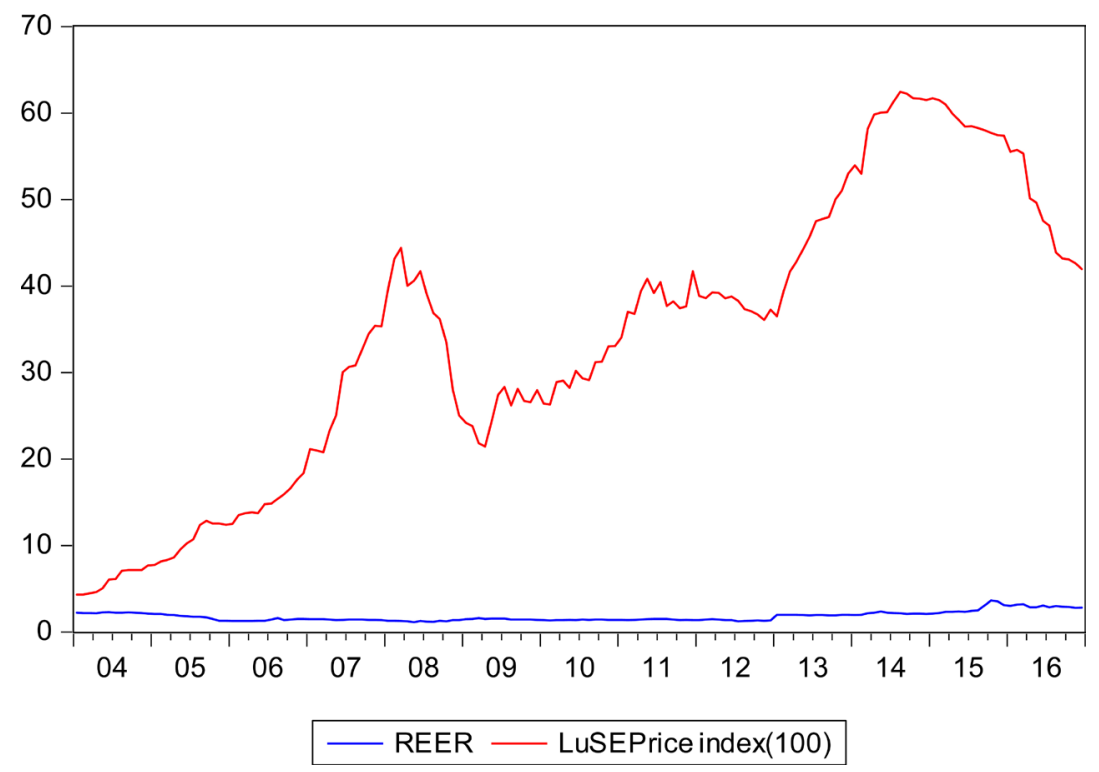

Source: Bank of Zambia and Lusaka Securities exchange.

Figure 2. Graphs showing the LuSE price index and Real Effective Exchange Rates (REER). 
exchange rates seem to be stable. They both move around the non Zero or constant meaning the variables might not be stationary.

\subsubsection{Diagnostic Tests}

Before the estimation was done some diagnostic test were done among them was the normality test for the dependent variable, and the Unit root test.

\section{Normality of dependent variable}

A very important assumption in regression is that the dependent variable is normally distributed. A test whether the frequency distribution of the variable deviates from a normal distribution was done using Jarque-Bera statistics. If the Jarque-Bera probability test is non-significant ( $p>0.05)$, it tells that the distribution in the sample is not significantly different from a normal distribution (Field, 2005). The Jarque-Bera statist of 5.9063 with the probability of 0.0521 was observed, indicating that the LuSE Price Index was normally distributed.

\section{Unit root test.}

Before the estimation was done, unit root test were performed to confirm the stationarity properties of the data and in order to understand the order of integration of the variables into the long-run equation.

Ascertaining stationary property of data is vital in time series. Carrying out estimation without establishing whether data is stationary or not is equivalent to assuming that time series data is stationary, implying that it's mean, variance and autocovariance remain constant overtime (Gujarati, 2003).

However, time series data in most cases may not be stationary implying that the mean, variance and the auto covariance of such data may not be constant over time and therefore regression results from such estimation may be spurious or wrong. After establishing stationary property of the data, cointegration test were performed to establish the long-run relationship of the variables.

The results of the unit root tests using the Augmented Dickey-Fuller (ADF) tests are presented in Table 1 below.

If the data is stationary (has no unit root) the $t$ value, should be greater than the critical values in absolute terms and the $\mathrm{p}$ value should be significant (less than 0.05).

Table 1. Summary of ADF unit root test results.

\begin{tabular}{|c|c|c|c|c|c|}
\hline \multirow{3}{*}{ Description } & \multicolumn{4}{|c|}{ Differencing } & \multirow{3}{*}{ Order of Integration } \\
\hline & \multicolumn{2}{|c|}{ Levels } & \multicolumn{2}{|c|}{ First Difference } & \\
\hline & t-Value & P-Value & t-Value & P-Value & \\
\hline LuSE Index & -2.0779 & 0.5535 & -4.5611 & 0.0017 & $\mathrm{I}(1)$ \\
\hline REER & -1.941974 & 0.0540 & -9.9055 & 0.0000 & $\mathrm{I}(1)$ \\
\hline \multirow[t]{3}{*}{ Test critical values: } & \multicolumn{2}{|c|}{$1 \%$ level } & \multicolumn{2}{|c|}{-4.019561} & \\
\hline & \multicolumn{2}{|c|}{$5 \%$ level } & \multicolumn{2}{|c|}{-3.439658} & \\
\hline & \multicolumn{2}{|c|}{$10 \%$ level } & \multicolumn{2}{|c|}{-3.144229} & \\
\hline
\end{tabular}

Source: Generated by the authors (2017). 
The results show that:

The LuSE index has a unit root (not stationary) because the ADF statistic ( $\mathrm{t} \alpha$ ) 2.0779 is not greater than the critical values of $4.0195,3.4396$ and 3.1444 at all the levels of significant (1\%, 5\% and $10 \%$ ) and the $\mathrm{P}$ value of 0.5535 is not significant, but after the first differencing it becomes stationary as (t $\alpha) 4.5611$ is greater than all the critical values of $4.5611,4.0195$ and 3.1442 at all levels of significance and the $\mathrm{p}$ value of 0.0017 is significant thus integrated of the order one $\mathrm{I}(1)$.

The REER has a unit root (not stationary) because the ADF statistic (t $\alpha$ ) 1.941974 is not greater than the critical values of $4.0195,3.4396$ and 3.1444 at all the levels of significant $(1 \%, 5 \%$ and $10 \%)$ and the $\mathrm{P}$ value of 0.0540 is not significant, but after the first differencing it becomes stationary as ( $\mathrm{t} \alpha$ ) 9.9055 is greater than all the critical values of 4.5611, 4.0195 and 3.1442 at all levels of significance and the $\mathrm{p}$ value of 0.0000 is significant thus integrated of the order one $\mathrm{I}(1)$.

\subsubsection{Long-Run Estimation Based on Cointegration Analysis}

Since the variables were discovered to have unit roots meaning that they are non-stationary at level, but became stationery after the first difference, a cointegration test was performed in order to test whether the variables were cointegrated or not. The presence of a cointegrating relationship means that the variables have a long-run equilibrium relationship and therefore forms a basis for the Vector Error Correction specification. Three steps were followed 1) Lag length selection 2) cointegration test and 3) Auto Regression distribution lag bound tests. If the variable were found to be cointegrated.

\section{1) Lag length selection}

In the first step of establishing the lag length unrestricted Vector Auto Regression estimation was undertaken in order to come up with an appropriate lag length to be used when establishing cointegration among the variables of. A lag length of five was selected as an appropriate based on the sequential modified LR test statistic and Akaike information criterion (AIC)

\section{2) Cointegration test}

The Johansson Cointegration test was done for the Stock Index as a dependent variable and exchange rates as independent variables. A cointegration exists if the trace statist value is more than the critical value and the probability is significant or if the error correction, variable in the Error Correction model has a negative sign and significant. The results for Johansson cointegration test in $\mathrm{Ta}$ ble 2 shows that there is contegration as the trace statist value or 17.13837 is more than the critical value of 15.49471 and the probability value of 0.0280 is significant. This indicates that there is a long-run relationship between. LuSE Index exchange rates in Zambia. This situation is similar to the findings of the study done by Nordin et al. (2014).

\section{3) Auto Regression distribution lag bound tests.}

Since the variables were found to have a long-run relationship Auto Regression distribution lag bound tests was done to establish the long-run coefficients. 
Table 3 shows the results for the Auto Regression distribution lag bound tests.

From the results, the estimated coefficient for REER is negative but statistically in significant. This also indicates that there is a long-run relationship, although it impact is negligible.

The estimated coefficient for REER is negative, but statistically insignificant as the $\mathrm{p}$ value is 0.7309 is more 0.05 . This indicates that the exchange rate has no significant long-run effect on the LuSE Index. Mixed empirical results showing the positive and negative effect of the exchange rate towards the stock market index have been found. For example Bhattacharya and Mukherjee (2003) found no relationship. Nordin et al. (2014) found a positive relationship in Malaysia, although earlier studies conducted in Malaysia by Rahman et al. (2009) showed no relationship and Sichoongwe (2016) found a negative relation in Zambia although in his study a different methodology was used and market capitalization instead of stock price index.

\subsubsection{Short-Run Estimation Based on Vector Error Correction Model (VECM)}

The result in Table 4 shows that the exchange rate has no short-run impact on the stock market as the coefficient on the REER is statistically insignificant. It is important to note that the error correction, variable has the negative sign and its statistically significant confirming the presence of the long-run relationship among the variables.

Table 2. Cointegration rank trace test analysis results.

\begin{tabular}{cccccc}
\hline $\begin{array}{c}\text { Cointegrated } \\
\text { variable }\end{array}$ & $\begin{array}{c}\text { Hypothesized } \\
\text { No. of CE (s) }\end{array}$ & Eigevalue & Trace Statistic & $\begin{array}{c}0.5 \\
\text { Critical Value }\end{array}$ & Prob \\
\hline $\begin{array}{c}\text { Stock Index, } \\
\text { REER }\end{array}$ & None & 0.087055 & 17.13837 & 15.49471 & 0.0280 \\
\hline
\end{tabular}

Source: Generated by the authors (2017).

Table 3. Auto regression distribution lag bound tests.

\begin{tabular}{ccccc}
\hline Variable & Coefficient & Std. Error & t-Statistic & Prob. \\
\hline Log LuSE Index $(-1)$ & -0.025164 & 0.006973 & -3.608988 & 0.0004 \\
REER $(-1)$ & -0.002715 & 0.007880 & -0.344605 & 0.7309 \\
\hline
\end{tabular}

Source: Generated by the authors (2017).

Table 4. ECM short-run results.

\begin{tabular}{cccc}
\hline Variable & Coefficient & t-Statistic & Prob. \\
\hline C & 0.949619 & 7.253721 & 0.0000 \\
REER & -0.002325 & -0.120104 & 0.9046 \\
Error Correction Variable & -8.835867 & -5.533573 & 0.0000 \\
\hline
\end{tabular}

Source: Generated by the authors (2017). 


\section{Conclusion}

This study investigated the impact of exchange rate on the Lusaka Securities and Exchange. By employing the Auto Regression distribution lag (ARDL) bound tests, cointegration and Error Correction Model (ECM) the results indicated the existence of cointegration (long-run) but no short-run relationships was observed. As a result of these cointegrating relationships, there are possibilities for investors to earn excess returns. In contrast, if the market is efficient, the investors would not be able to earn any abnormal returns because the security prices will adjust rapidly to the arrival of new information, thus the current prices reflect all information about the security.

As a result of these cointegrating relationships, there might be possibilities for investors to earn excess returns. This is in contrast with the efficient market hypothesis were the investors would not be able to earn any abnormal returns because the security prices will adjust rapidly to the arrival of new information, thus the current prices reflect all information about the security.

Therefore, investors should keep monitoring the movement of the exchange rate in order to mitigate investment risks. Monitoring the movement of the exchange rate will help the investors to make informed decisions on their investments and provide them with information about how the stock market is being exposed to the outside world. Policy makers should create a policy regime that will stimulate country's export and minimize on imports in order to stabilize and strengthen the local currency. For this to be done, policy makers require empirical data on the relationship between the exchange rate and the stock market in the local context. Without this data and relying on data from developed countries it will be difficult to create the policies that will enhance the performance of the local currency and the stock market.

\section{References}

Bhattacharya, B., \& Mukherjee, J. (2003). Casual Relationship between Stock Market and Exchange Rate, Foreign Exchange Reserves and Value of Trade Balance. 5th Annual Conference on Money and Finance in India, New Delhi, 12 August 2003, 12-22.

Branidharan, S. (2016). The Dynamic Long-Run and Short-Run Linkages between Exchange Rates and BSE Sensex Return. IPE Journal of Management, 6, 92-105.

Field, A. (2005). Discovering Statistics Using SPSS. London: SAGE Publication.

Gujarati, D. (2003). Basic Econometrics. Irwin, NJ: McGraw-Hill.

Iscan, E. (2014). The Relationship between Commodity Prices and Stock Price: Evidence from Turkey. SED-2014-2968.

Johansen, S. (1996). Likelihood Based Inference in Cointegrated Vector Autoregressive Models. Oxford: Oxford University Press.

Khan, E. A., \& Ali, R. (2015). Causality Analysis of Volatility in Exchange Rate and Stock Market Prices: A Case Study of Pakistan. Asian Economic and Financial Review, 5, 805-815

Komain, J. (2012). Linkages between Thai Stock and Foreign Exchange Markets under the Floating Regime. Journal of Financial Economics Policy, 4, 305-319. 
https://doi.org/10.1108/17576381211279280

Mishra, A. K. (2004). Stock Market and Foreign Markets in India: A They Related. South Asian Journal of Management, 11, ABI/INFORM Collection. https://doi.org/10.1177/139156140400500202

Mlambo, C., Maradza, A., \& Sibanda, K. (2013). Effects of Exchange Rate Volatility on the Stock Market: A Case Study of South Africa. Mediteranean Journal of Social Science, 4, 561-570. https://doi.org/10.5901/mjss.2013.v4n14p561

Nordin, N., Nordin, S., \& Ismail, R. (2014). The Impact of Commodity Prices, Interest Rate and Exchange Rate on Stock Market Performance: An Empirical Analysis from Malaysia. Malaysian Management Journal, 18, 39-52.

Odhiambo Odera (2012). Theoretical Issues on the African Stock Markets and Portfolio Performance. Journal of Economics and International Finance, 4, 19-28.

Rahman, A., Abdul, Noor, Z., Mohd, S., \& Fauziah, H. T. (2009). Macroeconomic Determinants of Malaysian Stock Market. African Journal of Business Management, 3, 95-106.

Sichoongwe, K. (2016). Effects of Exchange Rate Volatility on the Stock Market. The Zambian Experience, 7, 114-119.

Singh, A. (1999). Should Africa Promote Stock Market Capitalisation? Journal of International Development, 11, 343-365. https://doi.org/10.1002/(SICI)1099-1328(199905/06)11:3<343::AID-JID593>3.0.CO;2Q

Singh, G. (2015). The Relationship between Stock Price and Exchange Rate in India. An Empirical Study.

Suriani, S., Kumar, D. M., Jmil, F., \& Muneer, S. (2015). Impact of Exchange Rate on Stock Market. International Journal of Economic and Financial Issues, No. 5, 385-388.

United Nations Economic Commission for Africa (UNECA) (2015). Country Profile. Zambia.

Wongbangpo, P., \& Sharma, S. C. (2002). Stock Market and Macroeconomic Fundamental a Dynamics on Formation: ASEAN-5 Countries. Journal of Asian Economics, 13, 27-51.

Yartey, C. A., \& Komla, C. (2007). Stock Market Development in Sub-Saharan Africa: Critical Issues and Challenges (pp. 1-33). IMF Working Paper.

Zia, Q. Z., \& Rahman, Z. (2011). The Causality between Stock Market and Foreign Exchange Markt of Pakistan. Interdisciplinary Journal of Contemporary Research in Busines, 3, 906-919. 